\title{
Anti-Bacterial Activity of Different Soaps Available in Local Market of Rawalpindi (Pakistan) against Daily Encountered Bacteria
}

\author{
Abbas $\mathrm{SZ}^{1^{*}}$, Hussain $\mathrm{K}^{2}$, Hussain $\mathrm{Z}^{2}$, Ali $\mathbf{R}^{3}$ and Abbas $\mathrm{T}^{4}$ \\ ${ }^{1}$ Microbiology Department, University of Sindh, Jamshoro, Pakistan \\ ${ }^{2}$ Microbiology Department, Kohat University of Science and Technology, Pakistan \\ ${ }^{3}$ Microbiology Department, University of Karachi, Pakistan \\ ${ }^{4}$ Department of Microbiology, Food Safety Research Group (FSRG), University of Karachi, Pakistan
}

*Corresponding author: Abbas SZ, Department of Microbiology, University of Sindh, Jamshoro, Pakistan, Tel: +92 22 9213181; E-mail: zabbas1144@yahoo.com

Received date: October 31, 2016; Accepted date: November 26, 2016; Published date: November 29, 2016

Copyright: ( 2016 Abbas SZ, et al. This is an open-access article distributed under the terms of the Creative Commons Attribution License, which permits unrestricted use, distribution, and reproduction in any medium, provided the original author and source are credited.

\begin{abstract}
The in vitro antibacterial activity of three well-known brands of medicated soaps available in local market of Rawalpindi was conducted by agar well diffusion and agar disc diffusion methods. Reference bacterial strains like Escherichia coli (ATCC25922), Staphylococcus aureus (ATCC25923) and Salmonella typhi (ATCC 6539) were treated with three different concentrations of $50 \mathrm{mg} \mathrm{mL}^{-1}, 100 \mathrm{mg} \mathrm{mL}^{-1}$ and $150 \mathrm{mg} \mathrm{mL}^{-1}$ each soaps. Three different soaps of brand name Safeguard manufactured by Procter and Gamble Pakistan, Lifebuoy manufactured by Unilever Pakistan and Dettol manufactured by Reckitt Benckiser Pakistan Limited. All brands of soaps gave satisfactory results. Antibacterial activity of these soaps was different from each other. Increasing concentration (150 mg/ $\mathrm{mL}>100 \mathrm{mg} / \mathrm{mL}>50 \mathrm{mg} / \mathrm{mL}$ ) of each showed good result against reference bacterial strain especially against Staphylococcus aureu sand Escherichia coli. Safeguard was much stronger in all the three soaps in their antibacterial activity, while Dettol was moderate in action against these bacterial strains having average inhibition zones. On the other hand Lifebuoy showed least anti-bacterial activity against both gram positive and gram negative bacteria especially against gram positive bacterial strain.
\end{abstract}

Keywords: Agar well diffusion method; Agar disc diffusion method; Zone of inhibition; Rawalpindi

\section{Introduction}

Soaps and other cleaning agents are extensively used for a very long time for different cleaning purposes [1]. For generations it has been thought that washing hands with soap and water is a measure of one's personal hygiene. Bacteria found everywhere in soil, water, air, sewage and on human body and hence of great importance with reference to health [2]. Soaps play a very important role both in cleaning and killing bacteria. To enhance their antibacterial activities some active ingredients are added to soap [3]. According to Osborne and Grobe that antibacterial soap can remove about $65-85 \%$ of bacterial flora from human skin [4].

As skin is the first line of defense, so most of the bacteria like Pseudomonas aureginosa and Staphylococcus aureus reside on skin and is the major cause of skin infections. Hand washing with antibacterial is of more importance in accordance with the health care associates as they may be the main cause of bacterial contamination either opportunistic or pathogens [5-6]. Soaps contain active ingredients that have an antibacterial activity and also the reducing power against the pyogenic skin infection caused by Staphylococcus aureus and other gram negative species of bacteria [7]. It is studied that an antibacterial soap is more effective in removing bacteria then a plain soap [8].

A huge number of chemical compounds are present that have the ability to stop the growth of bacteria and can kill them. These compounds are very large in number possibly 10,000 of which 1000 are being usually used in hospitals and homes. These chemical compounds exist in the form of solids, liquids and gases. Many groups of chemicals used to decrease or destroy microbes. Significant groups include halogens, phenols, soaps, detergents, ammonia compounds, alcohols, heavy metals, acids and certain extraordinary compounds [9].

A lot of cleaning agents are present in the market, which are presented in various forms with distinct formulation. Triclosan, trichlorocarbanilide and P-chloro-in-xylenol (PCMX/Chloroxylenol) are the commonly used anti-bacterial in medicated soaps. These are generally only contained at preservation level unless the product is clearly marked as antibacterial, antiseptic, or germicidal [10]. Some people consider that the antibacterial portion of soaps is effective against microorganisms and can prevent most communicable diseases, but researchers found that too much use of soaps can be a cause of spreading diseases instead of preventing them [11]. Too much use of medicated soaps might result in a resistant strain, and then the person is more prone to opportunistic skin infections [12].

The purpose of this study was to evaluate the antimicrobial activity of 3 different brands of antibacterial soaps available in the local market of Rawalpindi a district in the Punjab province against daily encountered bacteria present on the skin. Activities of the soaps were studied against the selected strains of bacteria to know their antibacterial effect. 


\section{Materials and Methods}

\section{Sample soaps collection}

The medicated soap samples used for the study were purchased from Shaheen Chemist, one of standard pharmacy chain in Rawalpindi city. The batch numbers, expiry dates and the presence or absences of the manufacturers seal were noted.

\section{List of soaps used}

Safeguard; Dettol; and Lifebuoy.

\section{Controls}

Acetic acid was used as positive control and Distilled water as negative control in well diffusion method, while gentamycin was used as positive control and sterile paper disc was used as negative control. The given controls were collected from Allied Axiom Chemical Pvt. Ltd. Karachi, Pakistan.

\section{Reference bacterial culture}

The reference bacterial cultures Staphylococcus aureus ATCC 25923, Escherichia coli ATCC 25922 and Salmonella typhi ATCC 6539 were provided by the Microbiology laboratory of Bio-Labs (Pvt.) Ltd. Islamabad Pakistan. Further the bacterial cultures were inoculated separately on nutrient agar plate and incubated at $37^{\circ} \mathrm{C}$ for $48 \mathrm{~h}$ in incubator. Strains were stored at $-70^{\circ} \mathrm{C}$ in $50 \%$ sterile glycerol and TSB [13].

\section{Preparation of test sample}

A sterile blade was used to scrap the soaps. Test sample was prepared in sterile distilled water in the concentrations of $50 \mathrm{mg} \mathrm{mL}^{-1}$, $100 \mathrm{mg} \mathrm{mL}^{-1}$ and $150 \mathrm{mg} \mathrm{mL}^{-1}$ of each soap and was dissolved in such a way that no foam is produced to form a stock solution. $100 \mu \mathrm{L}$ of each concentration was used in experiment. These stock solutions were then stored in a refrigerator in well-sealed containers for future use.

\section{Procedure}

To study the antibacterial activity of the soaps, two methods were used to determine the zone of inhibition:

Paper Disc Diffusion Method: A standard method of National Committee for Clinical Laboratory Standards NCCLS.

Agar Well Diffusion method [14].

\section{Disc diffusion method}

About 15-20 mL of Mueller-Hinton agar was poured on sterile glass Petri dishes $(90 \mathrm{~mm})$ and allowed to solidify. Agar surface of each plate was streaked by a sterile cotton swab with the reference bacterial strain. Paper Discs of $6 \mathrm{~mm}$ size were impregnated in $100 \mu \mathrm{L}$ of each sample and was placed on solidified agar plates at equal distance with control. The plates were allowed to standby for $30 \mathrm{~min}$. The plates were incubated at $37^{\circ} \mathrm{C}$ for $48 \mathrm{~h}$.

\section{Agar well diffusion method}

Same amount 15-20 mL of Mueller-Hinton agar was poured on glass petro plates of same size and allowed to solidify. Agar surface of each plate was streaked by a sterile cotton swab with the reference bacterial strain. Agar plate was punched with a sterile cork borer of 4 $\mathrm{mm}$ size and $100 \mu \mathrm{L}$ of each sample was poured with micropipette in the bore. The plates were allowed to standby for $30 \mathrm{~min}$. The plates were incubated at $37^{\circ} \mathrm{C}$ for $48 \mathrm{~h}$.

\section{Results and Discussions}

Two methods (Disc Diffusion Method and Well Diffusion Method) were adopted to determine the antibacterial activities of the different daily use market soap brands against gram positive $S$. aureus and gram negative pathogens like E. coli and $S$. typhi.

In the first step a volume of $100 \mu \mathrm{L}$ of different concentration (50 $\mathrm{mg} \mathrm{mL} L^{-1}, 100 \mathrm{mg} \mathrm{mL}^{-1}$ and $150 \mathrm{mg} \mathrm{mL}^{-1}$ ) of each soap, were tested by a familiar method called disc diffusion against $S$. aureus, E. coli and $S$. typhi and different inhibition zones were recorded as shown in Table 1.

In the second step same bacterial strain were treated with different soaps, by taking a $100 \mu \mathrm{L}$ of $\left(50 \mathrm{mg} \mathrm{mL}^{-1}, 100 \mathrm{mg} \mathrm{mL}^{-1}\right.$ and $150 \mathrm{mg}$ $\mathrm{mL}^{-1}$ ) of each, following another method known as Well Diffusion Method. Antibacterial activities of all the three soaps against selected bacterial strains were recorded in the form of inhibition zone and measured in millimetre with Vernier Caliper. The inhibition zones values of bacterial strains, against these soap brands were shown in Table 2.

As Tables 1 and 2 clearly indicated that the inhibition zone values of these disinfectants (soaps) were significantly different from each other. As results reflects that antibacterial activities (IZ) of these soaps was significantly different in increasing order as, Safeguard, Dettol and Lifebuoy respectively as $50 \mathrm{mgL}^{-1} \mathrm{mg}$ has strongest inhibition zones as compared to $100 \mathrm{mg} \mathrm{mL}^{-1}$ and $150 \mathrm{mg} \mathrm{mL}^{-1}$ respectively. It means more concentrated solution had strong antibacterial activity [15].

The results of both the methods clearly conveyed the message that safeguard soap was most effective against $E$. coli and $S$. aureus by drawing 9, 9.9, $12 \mathrm{~mm}$ and 9.2, 10.3, $12.1 \mathrm{~mm}$ inhibition zone respectively by DDM, while $8,9.7,11.8 \mathrm{~mm}$ and $8.2,9.2,12.6 \mathrm{~mm}$ (IZ) respectively by WDM. Despite this a gram negative $S$. typhi showed little resistance toward this soap by drawing 9.6, 11.8, $13.7 \mathrm{~mm}$ inhibition zones by first method and $9,10.7,14.3 \mathrm{~mm}$ zones by second method [3].

The present study of Dettol soap was found to be comparable with previous study (Russell and Hugo), as it was approved effective against $S$. aureus and $S$. typhi by drawing an inhibition zone of $9.3,12.1,15.2$ $\mathrm{mm}$ and $10.5,14.3,18.2 \mathrm{~mm}$ respectively in disc diffusion method, while $9.2,11.7,13.1 \mathrm{~mm}$ and 10.3, 14.2, $17.1 \mathrm{~mm}$ inhibition zones respectively in agar well diffusion method. Gram negative E. coli showed resistance by drawing comparatively minimum inhibition zones in both the methods as; $10.8,15.7,19.7 \mathrm{~mm}$ and 9.5, 14.6, 19.3 $\mathrm{mm}$ respectively. It proves that Dettol soap is less effective to encounter bacteria than safeguard. On the other hand Lifebuoy soap showed minimum inhibition zones against all bacterial strains in both the methods as in DDM 10. 7, 17.7, $26.8 \mathrm{~mm}, 11.5,19.4,30.4 \mathrm{~mm}$, and $10.5,16.3,22.6 \mathrm{~mm}$ by $E$. coli, $S$. aureus and $S$. typhi respectively. Similarly 12.8, 17.6, $22.5 \mathrm{~mm}, 13.9,19.7,25.9 \mathrm{~mm}$ and 12.6, 17.8, 21.9 $\mathrm{mm}$ inhibition zones were observed against $E$. coli, $S$. aureus and $S$. typhi respectively by WDM [16]. 
Citation: Abbas SZ, Hussain K, Hussain Z, Ali R, Abbas T (2016) Anti-Bacterial Activity of Different Soaps Available in Local Market of Rawalpindi (Pakistan) against Daily Encountered Bacteria. Pharm Anal Acta 7: 522. doi:10.4172/2153-2435.1000522

Page 3 of 3

\begin{tabular}{|c|c|c|c|c|c|c|c|c|c|}
\hline \multirow[t]{2}{*}{ Stock Solution } & \multicolumn{3}{|l|}{ Safeguard } & \multicolumn{3}{|l|}{ Dettol } & \multicolumn{3}{|l|}{ Lifebuoy } \\
\hline & $50 \mathrm{mg} / \mathrm{mL}$ & $100 \mathrm{mg} / \mathrm{mL}$ & $150 \mathrm{mg} / \mathrm{mL}$ & $50 \mathrm{mg} / \mathrm{mL}$ & $100 \mathrm{mg} / \mathrm{mL}$ & $150 \mathrm{mg} / \mathrm{mL}$ & $50 \mathrm{mg} / \mathrm{mL}$ & $100 \mathrm{mg} / \mathrm{mL}$ & $150 \mathrm{mg} / \mathrm{mL}$ \\
\hline Amount used & \multicolumn{3}{|c|}{$100 \mu \mathrm{L}$ of each } & \multicolumn{3}{|c|}{$100 \mu \mathrm{L}$ of each } & \multicolumn{3}{|c|}{$100 \mu \mathrm{L}$ of each } \\
\hline Escherichia coli & 9 & 9.9 & 12 & 10.8 & 15.7 & 19.7 & 10.7 & 17.7 & 26.8 \\
\hline Staphylococcus aureus & 9.2 & 10.3 & 12.1 & 9.3 & 12.1 & 15.2 & 11.5 & 19.4 & 30.4 \\
\hline Salmonella typhi & 9.6 & 11.8 & 13.7 & 10.5 & 14.3 & 18.2 & 10.5 & 16.3 & 22.6 \\
\hline
\end{tabular}

Table 1: Zone of inhibition ( $\mathrm{mm}$ ) of the mansion bacterial strains against three different soaps by DDM.

\begin{tabular}{|c|c|c|c|c|c|c|c|c|c|}
\hline \multirow[t]{2}{*}{ Stock Solution } & \multicolumn{3}{|l|}{ Safeguard } & \multicolumn{3}{|l|}{ Dettol } & \multicolumn{3}{|l|}{ Lifebuoy } \\
\hline & $50 \mathrm{mg} / \mathrm{mL}$ & $100 \mathrm{mg} / \mathrm{mL}$ & $150 \mathrm{mg} / \mathrm{mL}$ & $50 \mathrm{mg} / \mathrm{mL}$ & $100 \mathrm{mg} / \mathrm{mL}$ & $150 \mathrm{mg} / \mathrm{mL}$ & $50 \mathrm{mg} / \mathrm{mL}$ & $100 \mathrm{mg} / \mathrm{mL}$ & $150 \mathrm{mg} / \mathrm{mL}$ \\
\hline Amount used & \multicolumn{3}{|c|}{$100 \mu \mathrm{L}$ of each } & \multicolumn{3}{|c|}{$100 \mu \mathrm{L}$ of each } & \multicolumn{3}{|c|}{$100 \mu \mathrm{L}$ of each } \\
\hline Escherichia coli & 8 & 9.7 & 11.8 & 9.5 & 14.6 & 19.3 & 12.8 & 17.6 & 22.5 \\
\hline Staphylococcus aureus & 8.2 & 9.2 & 12.6 & 9.2 & 11.7 & 13.1 & 13.9 & 19.7 & 25.9 \\
\hline Salmonella typhi & 9 & 10.7 & 14.3 & 10.3 & 14.2 & 17.1 & 12.6 & 17.8 & 21.9 \\
\hline
\end{tabular}

Table 2: Zone of inhibition (mm) of the mansion bacterial strains against three different soaps by AWDM.

\section{Conclusion}

The present study suggested that the choice of soap should be that which is effective against disease causing bacteria in a small amount. This study proved that all the soaps had antibacterial activity against all the given bacterial strains but Safeguard soap in the most effective soap against all the given bacterial soap and should be the first choice for daily use [17]. Dettol soap was at second number. Lifebuoy soap had the least antibacterial activity against all the given bacterial strains [16].

\section{Acknowledgement}

We acknowledge the Microbiology and Chemistry departments of University of Sindh and University of Karachi in providing logistic support, we also acknowledge Microbiology department of Kohat University and Allied Axiom Chemical Pvt. Limited in processes of samples for antimicrobial analysis of different soaps.

\section{References}

1. Mwambete KD, Lyombe F (2011) Antimicrobial Activity of Medicated Soaps Commonly Used By Dar es Salaam Residents in Tanzania. Indian J Pharm Sci 73: 92-98.

2. Johnson SA, Goddard PA, Ilife C, Timmens B, Richard AH, et al. (2002) Comparative susceptibility of resident and transient hand bacteria to para-chlorometa-xylenol and triclosan. J Appl Microbiol 93: 336-344.

3. Saba R, Adeel H, Shahida H (2009) Antibacterial Activity of Soaps against daily encountered bacteria. Afr J Biotechnol 8: 1431-1436.

4. Osborne RC, Grube J (1982) Hand disinfection in dental practice. J Clin Prev Dent 4: 11-15.

5. Fluit AC, Schmitz FJ, Verhoef J (2001) Frequency and Isolation of pathogens from blood stream, nosocomial pneumonia, skin and soft tissues, and urinary tract infections occurring in European patients. Clin Microbiol Infect 20: 188-191.

6. Higaki S, Kitagawa T, Kagoura M, Morohashi M, Yamagish T (2000) Predominant Staphylococcus aureus isolated from various skin diseases. J Int Med 28: 87-190.

7. Richards MJ, Edwards JR, Culver DH, Gaynes RP (1999) Nosocomial infections in medical intensive care units in the United States, National Nosocomial Infections Surveillance System. Crit Care Med 27: 887-892.

8. Selvamohan T, Sandhya V (2012) Studies on bactericidal activity of different soaps against bacterial strains. J Microbiol Biotech 2: 646-650.

9. Lucet JC (2002) Mination before and after different hygiene techniques: a randomized clinical trial. J Hosp Infect 50: 276-280.

10. Rama BP, Prajna PS, Vinita PM, Pavithra S (2011) Antimicrobial Activities of Soap and Detergents. Adv Biores 2: 52-62.

11. Larson E, McGinley K, Grove GL, Leyden JJ, Talbot GH (1989) Physiologic, microbiologic and seasonal effects of hand washing on the skin of health care personnel. Am J Infect Cont 14: 5-90.

12. Poole K (2002) Mechanisms of bacterial biocide and antibiotic resistance. J Appl Microbiol 92: 555-564.

13. White DG, McDermolt PF (2001) Biocides, drug resistance and microbial evolution. Curr Opin Microbiol 4: 313-317.

14. Olga CADS, Marta CDC, Aida PDRH, Olga MDN (2001) A Comparative Study of Preservation and Storage of Haemophilus influenzae Mem Inst Oswaldo Cruz. Rio de Janeiro 96: 583-586.

15. Stanley CB, Walton EG (1968) Preparation of Agar Wells for Antibiotic Assay. App Microb 16: 1611-1612.

16. Kalsoom F, Shazia B, Farzana J, Syed NHS (2004) Study of bactericidal activity of different soaps against Salmonella typhi. J Res Sci 15: 361-368.

17. Farzan K, Shazia B, Ismail T, Asad MHHB, Rasool F, et al. (2011) Comparative bactericidal activity of various soaps against gram-positive and gram-negative bacteria. Sci Res Essays 6: 3514-3518. 